Research report

\title{
Possible involvement of the CA1 GABAergic system on harmaline induced memory consolidation deficit
}

\author{
Mohammad Nasehi ${ }^{\mathrm{a}, *}$, Naghmeh Saadati $^{\mathrm{b}}$, Fatemeh Khakpai ${ }^{\mathrm{c}}$, \\ Mohammad-Reza Zarrindast ${ }^{\mathrm{a}, \mathrm{c}, \mathrm{d}, \mathrm{e}, \mathrm{f}, \mathrm{g}, * *}$ \\ a Cognitive and Neuroscience Research Center (CNRC), Tehran Medical Sciences Branch, Islamic Azad University, Tehran, Iran \\ b Department of Biology, Faculty of Basic Sciences, Northern Branch, Islamic Azad University, Tehran, Iran \\ ${ }^{c}$ Institute for Cognitive Science Studies (ICSS), Tehran, Iran \\ d Department of Pharmacology School of Medicine, Tehran University of Medical Sciences, Tehran, Iran \\ e Iranian National Center for Addiction Studies, Tehran University of Medical Sciences, Tehran, Iran \\ ${ }^{\mathrm{f}}$ School of Cognitive Sciences, Institute for Research in Fundamental Sciences (IPM), Tehran, Iran \\ ${ }^{g}$ Medical Genomics Research Center, Tehran Medical Sciences Branch, Islamic Azad University, Tehran, Iran
}

\section{A R T I C L E I N F O}

\section{Article history:}

Received 25 July 2016

Received in revised form

27 December 2016

Accepted 11 January 2017

Available online 19 January 2017

\section{Keywords:}

Harmaline

$\mathrm{GABA}_{\mathrm{B}}$ receptor

The CA1 region

Step-down

Memory

\begin{abstract}
A B S T R A C T
Activation of the $G A B A_{B}$ receptors inhibit learning and memory processes. The current research was designed to examine the role of dorsal hippocampal (CA1) $G A B A_{B}$ receptors on harmaline induced memory consolidation deficit in mice. For this purpose, the effects induced by the $G_{A B} A_{B}$ antagonist phaclofen and the $G_{A B A}$ agonist baclofen on memory consolidation were assessed by using the stepdown inhibitory avoidance task. Furthermore, the possible involvement of harmaline on $\mathrm{GABA}_{\mathrm{B}}$ receptor's effects was also assessed through using the same behavioral procedure. In a first dose response experiments, post-training intra-CA1 injections of phaclofen did not change while baclofen $(0.1 \mu \mathrm{g} / \mathrm{mouse})$ impaired animals' performance in this task, suggesting a modulation of storage of information. Moreover, Post-training intra-peritoneal (i.p.) infusion of harmaline ( 2 and $5 \mathrm{mg} / \mathrm{kg}$ ) also decreased memory consolidation. Interestingly, phaclofen at the sub-threshold dose $(0.001 \mu \mathrm{g} / \mathrm{mouse}$, intra-CA1), successfully antagonized the deficits on memory consolidation induced by the highest doses of harmaline (2 and $4 \mathrm{mg} / \mathrm{kg}$, i.p.). On the other hand, non significant dose of baclofenc $(0.001 \mu \mathrm{g} / \mathrm{mouse}$, intra-CA1) potentiated impairment of memory consolidation induced by harmaline $(2 \mathrm{mg} / \mathrm{kg}$, i.p.). In addition in all experiments, locomotor activity did not alter significantly. These results indicate a) that the CA1 GABA receptors are involved in memory consolidation $b$ ) that harmaline interact with the $C A 1 \mathrm{GABA}_{B}$ receptors in modulation of memory consolidation.
\end{abstract}

(C) 2017 Published by Elsevier Inc.

\section{Introduction}

$\gamma$-Aminobutyric acid (GABA), the most abundant inhibitory neurotransmitter in the brain, acts at different pharmacologically distinct receptor subtypes: the ionotropic $\mathrm{GABA}_{\mathrm{A}}$ and $\mathrm{GABA}_{\mathrm{C}}$ receptors (both of which activate $\mathrm{Cl}^{-}$currents) and the metabotropic $\mathrm{GABA}_{\mathrm{B}}$ receptor (G-protein coupled receptor) (Couve et al., 2000; Li et al., 2004; Zarrindast et al., 2006). There are experimental studies that the $\mathrm{GABA}_{\mathrm{B}}$ receptor is participated in learning and

\footnotetext{
* Corresponding author.

** Corresponding author at: Department of Pharmacology, School of Medicine, Tehran University of Medical Sciences, Tehran, 13145-784, Iran.

E-mail addresses: nasehi@iricss.org (M. Nasehi),Zarinmr@ams.ac.ir (M.-R. Zarrindast).
}

memory processes, though its exact function is not yet explained (Mondadori et al., 1993; Pitsikas et al., 2003). It has been demonstrated that GABA plays a controlling role on the balance of excitability and inhibitory states in the cortex and hippocampus (Nazari-Serenjeh et al., 2011; Paulsen and Moser, 1998). Almost $10 \%$ of the CA1 region interneurons are related to the GABAergic systems (Buzsaki, 1997). It appears that the hippocampal output is partly controlled via $\mathrm{GABA}_{A}$ or $\mathrm{GABA}_{\mathrm{B}}$ receptors (Ling and Benardo, 1994). There are studies showing that blockade of hippocampal $\mathrm{GABA}_{\mathrm{B}}$ receptor results in suppression of hippocampal long-term potentiation and spatial learning (Brucato et al., 1996).

Harmaline, a $\beta$-carboline alkaloid derived from the seeds of the plant Peganum harmala (Frostholm et al., 2000), is a monoamine oxidase inhibitor (Jimenez et al., 2008). Recently, harmaline has been revealed to lower voltage-gated calcium channel currents (Splettstoesser et al., 2005), resulting in decreased neuron excita- 
tion. On the other hand, harmaline is known to affects non spatial and non aversive memory tasks, increasing predominantly longterm memory (LTM) (de Montigny and Lamarre, 1973). Numerous evidences have documented that harmaline has interaction with GABA-benzodiazepine receptors (Weiss et al., 1995). Moreover, there are reports showing that $\beta$-carboline alkaloids increase GABA responses in the spinal cord neurons (Skerritt and Macdonald, 1984), and cerebral cortex (Malatynska et al., 1992). In view of (1) the existence of interaction between GABA receptors and harmaline (Malatynska et al., 1992; Skerritt and Macdonald, 1984; Weiss et al., 1995), and (2) the role of hippocampus (Khakpai et al., 2012; Khakpai et al., 2013; Khakpai et al., 2016), harmaline (Nasehi et al., 2014; Nasehi et al., 2015; Nasehi et al., 2016), and GABA receptors (Nakagawa and Takashima, 1997; Shahidi et al., 2008; Yousefi et al., 2012) in learning and memory processes, the aim of the current research was to investigate the effects of harmaline and $\mathrm{GABA}_{\mathrm{B}}$ receptors on memory consolidation and locomotor activity in the step-down inhibitory avoidance and open field test. In the first set of experiments, the effect of the inhibition and stimulation of $\mathrm{GABA}_{\mathrm{B}}$ receptors in the CA1 area on memory consolidation was investigated. In the second set of experiments, we evaluated the effect of harmaline on inhibitory avoidance memory. In the third set of experiments, we examined whether the inactivation or activation of $\mathrm{GABA}_{\mathrm{B}}$ receptors of the CA1 area affect harmaline-induced memory consolidation deficit.

\section{Materials and methods}

\subsection{Animals}

Male, five-eight weeks old NMRI mice (University of Tehran, Tehran, Iran), weighing $25-30 \mathrm{~g}$ were used in this study. The subjects were housed in polypropylene cages, ten per cage, in a regulated environment $\left(22 \pm 2{ }^{\circ} \mathrm{C} ; 50-55 \%\right.$ relative humidity; 12-h light:dark cycle, lights on at 07:00 h), with free access to food and water. Experiments were carried out in the room where only these subjects were housed, and took place between 9:00 h and 12:00 h. Behavioral researches and assessments were done by experimenters who were unconscious of the pharmacological treatment.

Procedures including subjects and their care were conducted in according with the international guidelines in agreement with National and International laws and policies (the Ethics Committee of the Faculty of Science of the University of Tehran).

\subsection{Cannula guide implantation}

All surgical procedures were carried out under ketamine/xylazine ( $50 \mathrm{mg} / \mathrm{kg}$ and $5 \mathrm{mg} / \mathrm{kg}$, respectively) anesthesia. Two stainless steel, 22-gauge guide cannulas were bilaterally implanted $1 \mathrm{~mm}$ above the intended site of injection according to the atlas of Paxinos and Franklin (Paxinos and Franklin, 2001). Stereotaxic coordinates for the CA1 area of the dorsal hippocampi were: anteroposterior $(\mathrm{AP})=-2 \mathrm{~mm}$ from the bregma, mediolateral $(\mathrm{ML})= \pm 1.6$ from the sagittal suture and dorsoventral $(\mathrm{DV})=-1.5 \mathrm{~mm}$ from the skull surface. Cannulas were secured to anchor jeweler's screws with dental acrylic cement. To avoid clogging, stainless steel stylets (27 gauge) were located in the guide cannulas until the subjects were given the CA1 injections. All subjects were allowed 5-7 days to recover from surgery and clear anesthetic.

\subsection{Memory testing and apparatus}

The inhibitory avoidance behavior was studied in one-trial learning, step-down type, which uses the natural preference of mice for a dark location. The inhibitory avoidance apparatus consisted of a dark compartment $\left(20 \times 20 \times 15 \mathrm{~cm}^{3}\right)$ with a stainless steel grid floor and a descending door opened in its front center communicating with a small illuminated platform $\left(5 \times 5 \mathrm{~cm}^{2}\right)$ attached to it and elevated $1 \mathrm{~m}$ from the floor. The subjects were not exposed to the inhibitory avoidance apparatus before the learning trial. During training session, each mouse was quietly placed in the illuminated platform. As it stepped all paws into the dark compartment received a footshock of $1.2 \mathrm{~mA}, 50 \mathrm{~Hz}, 1 \mathrm{~s}$, which produces median retention scores at the ceiling. The retention test session was done $24 \mathrm{~h}$ after training. Therefore, each mouse was located on the platform again, and the step-down latency was measured. When the mouse stepped into the dark compartment or failed to cross in five min, the retention test was finished. In the second case the mouse was instantly removed from the platform and assigned a score of five min. The retention test session was performed with no footshock.

\subsection{Measurement of locomotor activity}

Locomotor activity was measured using an locomotion apparatus (Borj Sanat Co, Tehran, Iran) that consists of clear perspex container box $\left(30 \times 30 \times 40 \mathrm{~cm}^{3}\right)$ with wire meshed floor equipped with two arrays of 16 infrared photocells. The number of movement from one photocell to another was measured as the locomotor activity within five min period.

\subsection{Drugs}

The drugs used in the present study were harmaline (1-methyl7-methoxy-3,4-dihydro-b-carboline) from Sigma (St. Louis, MO), phaclofen (Sigma, St. Louis, CA, USA) and baclofen (Tocris, UK). The time of injection and doses of the drugs was selected based on our previous studies (Khanegheini et al., 2015; Nasehi et al., 2014; Nasehi et al., 2015; Nasehi et al., 2016). The compounds were tested at doses: harmaline: 1,2 and $4 \mathrm{mg} / \mathrm{kg}$, phaclofen: 0.001 , 0.01 , and $0.1 \mu \mathrm{g} /$ mouse, baclofen: $0.001,0.01$, and $0.1 \mu \mathrm{g} / \mathrm{mouse}$. The injected doses of the drugs were diverse due to diverse site of administration. The utilized doses of harmaline were given in $\mathrm{mg} / \mathrm{kg}$ because this drug injected i.p. On the other hand the utilized doses of GABAergic agents (phaclofen and baclofen) were given in $\mu \mathrm{g} /$ mouse because these drugs injected intra-CA1. Harmaline was dissolved in $0.9 \%$ physiological saline and the compound was stirred for $1 \mathrm{~h}$ previous obtaining the final solution; phaclofen and baclofen were dissolved in $0.9 \%$ physiological saline, just previous the experiments.

\subsection{Drug treatment}

For drug injection (immediately after training), the mice were gently restrained by hand; the stylets were removed from the guide cannulas and substituted by 27 -gauge administration needles ( $1 \mathrm{~mm}$ below the tip of the guide cannulas). Each administation unit was connected via polyethylene tubing to $1 \mu$ l Hamilton syringe. The left and right CA1 areas were injected with a $0.5 \mu \mathrm{l}$ solution on each side ( $1 \mu \mathrm{l} /$ mouse) over a $60 \mathrm{~s}$ period. The infusion needles were left in place an extra $60 \mathrm{~s}$ to allow diffusion and then the stylets were reinserted within the guide cannulas. The procedure has been explained in Table 1.

\subsection{Statistical analysis}

The data of step-down apparatus show individual variations, hence we analyze data by Kruskal-Wallis nonparametric oneway analysis of variance (ANOVA) followed via a two-tailed Mann-Whitney's $U$ test. Holmes Sequential Bonferroni Correction 
Table 1

The table clarifies experiments, groups of animals and the doses of drugs.

\begin{tabular}{|c|c|c|c|c|c|}
\hline Experiment & Figure & $\begin{array}{l}\text { Post-training } \\
\text { treatment (i.p.) }\end{array}$ & $\begin{array}{l}\text { Post-training } \\
\text { treatment (intra-CA1) }\end{array}$ & $\begin{array}{l}\text { Step-down latency } \\
\text { (Panels A, B or C) }\end{array}$ & $\begin{array}{l}\text { Locomotor activity } \\
\text { (Panels C, D, E or F) }\end{array}$ \\
\hline 1 & $\begin{array}{l}\mathrm{A} \text { and } \mathrm{B} \\
\mathrm{C} \text { and } \mathrm{D}\end{array}$ & - & $\begin{array}{l}\text { Phaclofen }(0.001,0.01 \text {, } \\
\text { and } 0.1 \mu \mathrm{g} / \text { mouse }) \\
\text { baclofen }(0.001,0.01 \text {, } \\
\text { and } 0.1 \mu \mathrm{g} / \text { mouse })\end{array}$ & $\begin{array}{l}\text { No effect } \\
\text { Decrease }\end{array}$ & $\begin{array}{l}\text { No effect } \\
\text { No effect }\end{array}$ \\
\hline 2 & $\begin{array}{l}\mathrm{A}, \mathrm{B} \text { and } \mathrm{C} \\
\mathrm{D}, \mathrm{E} \text { and } \mathrm{F}\end{array}$ & $\begin{array}{l}\text { harmaline }(1,2 \text {, and } \\
4 \mathrm{mg} / \mathrm{kg}) \text { harmaline }(1, \\
2 \text { and } 4 \mathrm{mg} / \mathrm{kg}) \\
\text { harmaline }(1,2 \text { and } \\
4 \mathrm{mg} / \mathrm{kg})\end{array}$ & $\begin{array}{l}\text { Saline }(1 \mu \mathrm{l} / \text { mouse }) \\
\text { Phaclofen } \\
(0.001 \mu \mathrm{g} / \text { mouse }) \\
\text { baclofen } \\
(0.001 \mu \mathrm{g} / \text { mouse })\end{array}$ & $\begin{array}{l}\text { Decrease } \\
\text { Increase } \\
\text { Decrease }\end{array}$ & $\begin{array}{l}\text { No effect } \\
\text { No effect } \\
\text { No effect }\end{array}$ \\
\hline
\end{tabular}

Test was used for paired comparisons when appropriate. The data of step-down latencies for ten mice in each experimental group were expressed as medians \pm interquartile ranges. Moreover, the data of locomotor activity analyzed through one/two-way ANOVA followed via post-hoc test that data expressed as mean \pm S.E.M.

\subsection{Experimental design}

Each experimental group consisted of ten mice and all mice were naive to the experimental tasks. Bilateral intra-CA1 injections of compounds volume were $1 \mu \mathrm{l} /$ mouse $(0.5 \mu \mathrm{l} /$ each side). All injections were carried out immediately after training. In experiments which subjects received two injections, firstly harmaline injected then phaclofen or baclofen administrated. Interval time between two administrations was five min.

\subsubsection{Experiment 1}

This experiment examined the effect of post-training intra-CA1 administration of $\mathrm{GABA}_{\mathrm{B}}$ receptor drugs on memory consolidation and locomotor activity. Eight groups of animals were used. Four groups of subjects received vehicle $(1 \mu \mathrm{l} /$ mouse) or different doses of phaclofen $(0.001,0.01$, and $0.1 \mu \mathrm{g} /$ mouse $)$ just after training. The other four groups received saline $(1 \mu \mathrm{l} /$ mouse $)$ or different doses of baclofen $(0.001,0.01$, and $0.1 \mu \mathrm{g} /$ mouse $)$ just after training.

\subsubsection{Experiment 2}

Experiment 2 evaluated the effects of post-training intraCA1 injection of $\mathrm{GABA}_{\mathrm{B}}$ receptor drugs on memory consolidation and locomotor activity under the amnesia induced by harmaline. Twelve groups of subjects were used. The subjects received saline $(1 \mu \mathrm{l} /$ mouse $)$ or different doses of harmaline $(1,2$ and $4 \mathrm{mg} / \mathrm{kg}$ ) just after training. These subjects received intra-CA1 posttraining vehicle $(1 \mu \mathrm{l} /$ mouse), sub-threshold dose of phaclofen (0.001 $\mu \mathrm{g} /$ mouse $)$ or baclofen $(0.001 \mu \mathrm{g} /$ mouse $)$ just after training.

\section{Results}

\subsection{Effects of $G A B A_{B}$ receptor drugs on memory consolidation and locomotor activity}

Fig. 1 shows the effects of post-training intra-CA1 administration of phaclofen and baclofen on the step-down latency and locomotor activity. Kruskal-Wallis ANOVA revealed that posttraining injection of phaclofen $(\mathrm{H}(3)=1.360, \mathrm{P}>0.05$, Fig. $1 \mathrm{~A}) \mathrm{did}$ not alter, while baclofen $(\mathrm{H}(3)=19.966, \mathrm{P}<0.001$, Fig. 1B) decreased the step-down latency. Post hoc analysis by Mann-Whitney's $U$ test indicated that baclofen $(0.1 \mu \mathrm{g} /$ mouse $)$ impaired memory consolidation, thus revealed an amnesic effect. Furthermore, one-way ANOVA displayed that phaclofen $[\mathrm{F}(3,36)=0.110, \mathrm{P}>0.05$, Fig. $1 \mathrm{C}]$ and baclofen $[F(3,36)=0.280, P>0.05$, Fig. $1 D]$ did not modify locomotor activity.
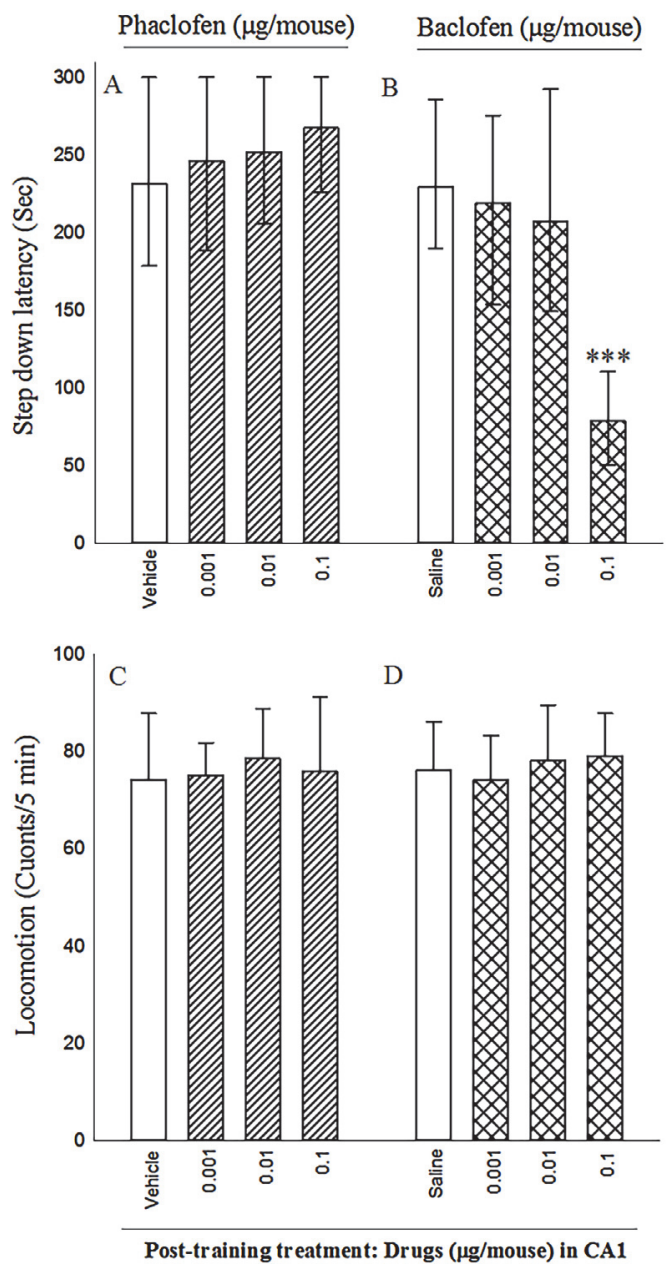

Fig. 1. The effects of saline, phaclofen and baclofen on step-down latency and locomotor activity. The animals received saline $(1 \mu \mathrm{l} /$ mouse), phaclofen $(0.001,0.01$, and $0.1 \mu \mathrm{g} /$ mouse, panel $\mathrm{A})$ and baclofen $(0.001,0.01$, and $0.1 \mu \mathrm{g} /$ mouse, panel B) just after training. The memory was measured $24 \mathrm{~h}$ after administration of drugs. Furthermore, locomotor activity was tested after memory testing. The step-down latency bars are indicated as median and quartile whereas locomotion bars are in mean \pm S.E.M. ( $n=10$, all groups; ${ }^{* * *} \mathrm{P}<0.001$ when compared to saline/saline group).

\subsection{Effects of post-training $G A B A_{B}$ receptor drugs injection on memory consolidation and locomotor activity under amnesia induced by harmaline}

The data of Fig. 2A showed that harmaline at doses of 2 and $4 \mathrm{mg} / \mathrm{kg}$ impaired memory consolidation [Kruskal-Wallis ANOVA analysis $(\mathrm{H}(3)=24.398, \mathrm{P}<0.001)$ followed by Mann-Whitney's $U$ test]. Also, one way ANOVA indicated that harmaline did not change locomotor activity $[F(3,36)=0.602, P>0.05$, Fig. $2 D]$. 

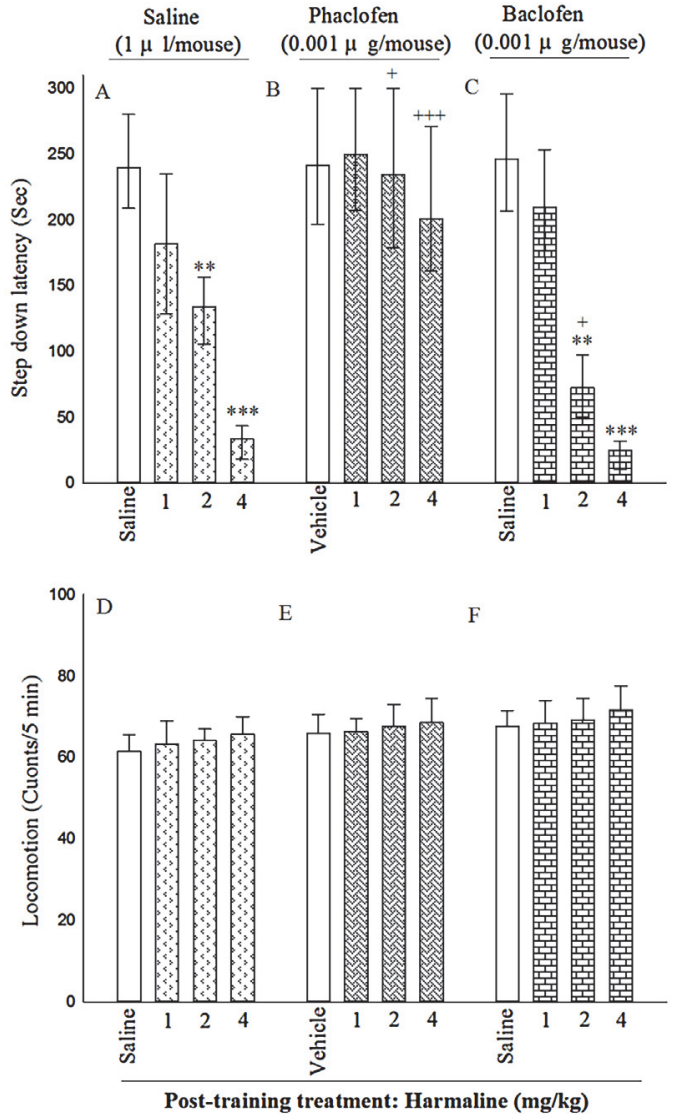

Fig. 2. The effects of GABAergic agents on memory consolidation and locomotor activity in the present and absence of harmanlie. Panel A and D shows the effects of post-training administration of harmaline (1, 2 and $4 \mathrm{mg} / \mathrm{kg}$, i.p.) on memory consolidation and locomotor activity. Also, Fig. 2 indicate the effects of post-training administration of phaclofen $(0.001 \mu \mathrm{g} /$ mouse, intra-CA1 $)$ and baclofen $(0.001 \mu \mathrm{g} / \mathrm{mouse}$, intra-CA1), respectively with harmaline (1, 2 and $4 \mathrm{mg} / \mathrm{kg}$, i.p.) on memory consolidation (Panels B and C) and locomotor activity (Panels E and F). The step-down latency bars are displayed as median and quartile but locomotion bars are in mean \pm S.E.M. $\left(\mathrm{n}=10\right.$, all groups; ${ }^{* *} \mathrm{P}<0.01$ and ${ }^{* * *} \mathrm{P}<0.001$ when compared to saline/saline group. $+\mathrm{P}<0.05$ and $+++\mathrm{P}<0.001$ when compared with respective harmaline/saline control group).

In addition, Kruskal-Wallis analysis displayed that a subthreshold dose of phaclofen $(0.001 \mu \mathrm{g} /$ mouse $)$ reversed memory impairment caused by harmaline ( 2 and $4 \mathrm{mg} / \mathrm{kg}$ ) [Kruskal-Wallis ANOVA, $\mathrm{H}(3)=2.299, \mathrm{P}>0.05$, Fig. 2B]. Also, two-way ANOVA exhibited that these interventions had no effect on locomotor activity $[F(7,56)=0.320, P>0.05$, Fig. $2 E]$.

In Fig. $2 \mathrm{C}$ right panel are seen the effects of baclofen on amnesia induced by harmaline [Kruskal-Wallis ANOVA, $\mathrm{H}(3)=28.934$, $\mathrm{P}<0.001$ ]. Mann-Whitney's $U$ test analysis showed that a subthreshold dose of baclofen $(0.001 \mu \mathrm{g} /$ mouse $)$ potentiated memory impairment induced by harmaline $(2 \mathrm{mg} / \mathrm{kg})$. Additionally, twoway ANOVA revealed that these interventions did not alter locomotor activity $[F(7,56)=0.615, P>0.05$, Fig. $2 F]$.

\subsection{Histology}

In order to confirm place of cannulas: after the testing session each mouse was deeply anesthetized (according to the surgery section) and a $4 \%$ methylene-blue solution was bilaterally injected into the CA1 $(0.5 \mu \mathrm{l} / \mathrm{site})$. Following decapitation, the brains removed and located in a $10 \%$ formaldehyde solution for several days. Then, the brains were sliced and the sites of administrations were verified according to the atlas of Paxinos and Franklin (Paxinos and

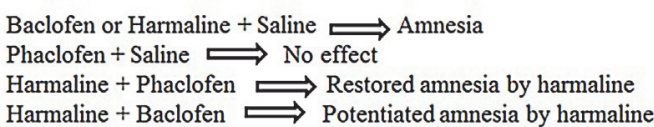

Harmaline + Baclofen $\Longrightarrow$ Potentiated amnesia by harmaline

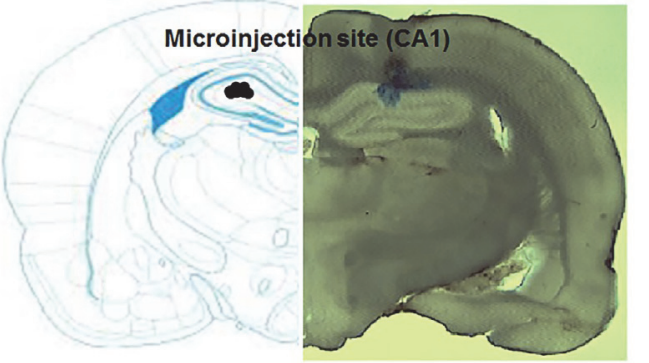

Fig. 3. Place of the injection cannulas tips in the CA1 regions of mice brain for all mice included in the data analyses (Paxinos and Franklin, 2001), and summary of experimental results.

Franklin, 2001) (Fig. 3). Only data from subjects with correct cannulas implants were used in the statistical analyses.

\section{Discussion}

The GABA systems have been revealed to play important roles in memory function (Farr et al., 2000; Myhrer, 2003). In our study, post-training intra-CA1 injection of phaclofen did not significantly modify memory consolidation in the step-down inhibitory avoidance task and locomotor activity in the open field test. In agreement with our data Zarrindast et al. (1998) reported that phaclofen did not alter the step-down latencies (Zarrindast et al., 1998). The reason why the $G A B A_{B}$ receptor antagonist had no effect on the inhibitory avoidance memory is not clear. We speculate that the $\mathrm{GABA}_{\mathrm{B}}$ receptor mechanism responds only when other neurotransmitter tone (such as cholinergic tone) is more prominent. Several line of evidences indicated that blockade of the $G A B A_{B}$ receptor produces conflicting results including either memory facilitation (Bianchi and Panerai, 1993; Mondadori et al., 1993) or memory impairment (Brucato et al., 1996). Also, our results showed that post-training intra-CA1 injection of baclofen impaired memory consolidation in the step-down inhibitory avoidance task but had no effect on locomotor activity in the open field test. It should be noted that enhancement of GABA activity may impair the memory process whereas drugs which decline GABA transmission can result in memory enhancement (Chapouthier and Venault, 2002). Therefore, it is possible that baclofen stimulate the postsynaptic GABA receptor, and so releases GABA, that in turn, decreases memory consolidation. Our result is in agreement with those presented by others, who indicated that baclofen stereotaxically administrated into the hippocampus impairs spatial learning in the place avoidance task (Stuchlik and Vales, 2009), circular open-field apparatus (Khanegheini et al., 2015), and water maze test (Arolfo et al., 1998). Furthermore, experimental researches indicated that systemic (Nakagawa et al., 1995), or local injections of baclofen into the basal forebrain (DeSousa et al., 1994), or septum (Stackman and Walsh, 1994) induced deficits in memory performance. The impairment of memory by intracerebroventricular injection of baclofen has also been described (Zarrindast et al., 2001; Zarrindast et al., 2004). On the other hand, various reports have documented that baclofen produces behavioral effects on cognition ranging from disruption of memory (Castellano et al., 1989; McNamara and Skelton, 1996; Stackman and Walsh, 1994), to enhancement of memory (Georgiev et al., 1988; Saha et al., 1993).

Furthermore, the data of this study indicated that post-training i.p. administration of harmaline impaired memory consolidation 
in the step-down inhibitory avoidance task but had no significant effect on locomotor activity in the open field test. Because harmaline is able to lower voltage-gated calcium channel currents (Splettstoesser et al., 2005), which causing in reduced neuron excitation, it could impaired memory consolidation. Calcium is an ubiquitous intracellular signal, responsible for regulating various cellular processes (Agrawal and Fehlings, 1996), which plays a vital role in synaptic communication (Yamauchi, 2005). Calcium influx stimulates cellular signaling pathways participated in memory consolidation, for example protein kinase $\mathrm{A}$, protein kinase $\mathrm{C}$, and mitogen-activated protein kinase pathways (Quevedo et al., 2004). A considerable body of evidence has highlighted the role of harmaline in excitation, euphoria (Rommelspacher et al., 1980), $\mathrm{Ca}^{2+}$-homeostasis (Moura et al., 2006), motor tremor (Lamarre and Mercier, 1971), and alteration in associative and motor learning (Du and Harvey, 1997). According to our results, it has been indicated that harmaline impaired memory acquisition (Nasehi et al., 2014; Nasehi et al., 2015; Nasehi et al., 2016), and associative and motor learning (Welsh, 1998). In contrast, some evidence showed that harmaline improved LTM (Moura et al., 2006). It is likely that the controversial reports may be due to methods, route of injection and/or the doses of drugs utilized.

In the next section of this study, interaction of harmaline and $\mathrm{GABA}_{B}$ receptors on memory consolidation were investigated. To evaluate the effect of harmaline on the $G A B A_{B}$ receptors, $G_{A B A}$ agents were challenged against different doses of harmaline that impaired memory consolidation. Our results exhibited that in mice trained under post-training i.p. injection of harmaline, post-training intra-CA1 injection of a sub-threshold dose of phaclofen and baclofen significantly modifies memory consolidation induced by higher doses of harmaline. These interventions did not change locomotor activity. Biochemical and pharmacological investigations indicated that harmaline and GABA-benzodiazepine receptors have interaction together (Weiss et al., 1995). Furthermore, the pharmacological studies revealed that $\beta$-carbolines alkaloids are found in the brain and to a certain extent influence the central and peripheral nervous systems (Farzin and Mansouri, 2006; Rook et al., 2010). There are evidences indicating that $\beta$-carboline alkaloids enhance GABA response in the brain (Malatynska et al., 1992). Moreover Malatynska et al. (1988) revealed that $\beta$-carboline alkaloid and GABA mechanisms have interaction in their biological resposes for instance electrophysiological and behavioral model systems (Malatynska et al., 1988). As mentioned above, GABA controls the balance of excitability and inhibitory states in the hippocampus (Nazari-Serenjeh et al., 2011). Thus, we propse that harmaline shares with phaclofen and baclofen the property of increasing and decreasing excitatory synaptic response of CA1 hippocampus neurons, respectively. So that, phaclofen and baclofen could significantly reversed and potentiated impairment of memory consolidation induced by harmaline, respectively. Consequently, harmaline and the CA1 GABA mechanisms interact with each other in the modulation of memory.

\section{Conclusion}

The current study indicated that post-training intra-CA1 administrations of phaclofen did not change, but baclofen decreased memory consolidation. Furthermore, post-training i.p. injection of harmaline impaired memory consolidation. Moreover, in our investigation post-training intra-CA1 administration of phaclofen restored, whereas baclofen potentiated impairment of memory consolidation induced by harmaline. In conclusion, the data presented in this research support the hypothesis of an interaction of harmaline with a GABAergic controlling role of neurotransmission in the hippocampal system. Nevertheless, further experiments are required to explain the interaction between harmaline and GABAergic system in the modulation of memory in the CA1 region.

\section{Conflict of interest}

The authors do not declare any conflict of interests.

\section{Acknowledgment}

The authors thank the Iran National Science Foundation (INSF) for providing the financial support for the project.

\section{References}

Agrawal, S.K., Fehlings, M.G., 1996. Mechanisms of secondary injury to spinal cord axons in vitro: role of $\mathrm{Na}+, \mathrm{Na}(+)-\mathrm{K}(+)$-ATPase, the $\mathrm{Na}(+)-\mathrm{H}+$ exchanger, and the $\mathrm{Na}(+)-\mathrm{Ca} 2+$ exchanger. J. Neurosci.: Off. J. Soc. Neurosci. 16, 545-552.

Arolfo, M.P., Zanudio, M.A., Ramirez, O.A., 1998. Baclofen infused in rat hippocampal formation impairs spatial learning. Hippocampus 8, 109-113.

Bianchi, M., Panerai, A.E., 1993. Reversal of scopolamine-induced amnesia by the GABAB receptor antagonist CGP 35348 in the mouse. Brain Res. Cogn. Brain Res. 1, 135-136.

Brucato, F.H., Levin, E.D., Mott, D.D., Lewis, D.V., Wilson, W.A., Swartzwelder, H.S 1996. Hippocampal long-term potentiation and spatial learning in the rat: effects of GABAB receptor blockade. Neuroscience 74, 331-339.

Buzsaki, G., 1997. Functions for interneuronal nets in the hippocampus. Can. J. Physiol. Pharmacol. 75, 508-515.

Castellano, C., Brioni, J.D., Nagahara, A.H., McGaugh, J.L., 1989. Post-training systemic and intra-amygdala administration of the GABA-B agonist baclofen impairs retention. Behav. Neural Biol. 52, 170-179.

Chapouthier, G., Venault, P., 2002. GABA-A receptor complex and memory processes. Curr. Top. Med. Chem. 2, 841-851.

Couve, A., Moss, S.J., Pangalos, M.N., 2000. GABAB receptors: a new paradigm in G protein signaling. Mol. Cell. Neurosci. 16, 296-312.

de Montigny, C., Lamarre, Y., 1973. Rhythmic activity induced by harmaline in the olivo-cerebello-bulbar system of the cat. Brain Res. 53, 81-95.

DeSousa, N.J., Beninger, R.J., Jhamandas, K., Boegman, R.J., 1994. Stimulation of $\mathrm{GABAB}$ receptors in the basal forebrain selectively impairs working memory of rats in the double Y-maze. Brain Res. 641, 29-38.

Du, W., Harvey, J.A., 1997. Harmaline-induced tremor and impairment of learning are both blocked by dizocilpine in the rabbit. Brain Res. 745, 183-188.

Farr, S.A., Flood, J.F., Morley, J.E., 2000. The effect of cholinergic, GABAergic, serotonergic, and glutamatergic receptor modulation on posttrial memory processing in the hippocampus. Neurobiol. Learn. Mem. 73, 150-167.

Farzin, D., Mansouri, N., 2006. Antidepressant-like effect of harmane and other beta-carbolines in the mouse forced swim test. Eur. Neuropsychopharmacol. 16, 324-328.

Frostholm, A., Evans, J.E., Cummings, S.L., Rotter, A., 2000. Harmaline-induced changes in gamma aminobutyric acid(A) receptor subunit mRNA expression in murine olivocerebellar nuclei. Brain Res. Mol. Brain Res. 85, 200-208.

Georgiev, V.P., Yonkov, D.I., Kambourova, T.S., 1988. Interactions between angiotensin II and baclofen in shuttle-box and passive avoidance performance. Neuropeptides 12, 155-158

Jimenez, J., Riveron-Negrete, L., Abdullaev, F., Espinosa-Aguirre, J., Rodriguez-Arnaiz, R., 2008. Cytotoxicity of the beta-carboline alkaloids harmine and harmaline in human cell assays in vitro. Exp. Toxicol. Pathol. 60, 381-389.

Khakpai, F., Nasehi, M., Haeri-Rohani, A., Eidi, A., Zarrindast, M.R., 2012 Scopolamine induced memory impairment; possible involvement of NMDA receptor mechanisms of dorsal hippocampus and/or septum. Behav. Brain Res. $231,1-10$.

Khakpai, F., Nasehi, M., Haeri-Rohani, A., Eidi, A., Zarrindast, M.R., 2013. Septo-hippocampo-septal loop and memory formation. Basic Clin. Neurosci. 4, $5-23$.

Khakpai, F., Nasehi, M., Zarrindast, M.R., 2016. The role of NMDA receptors of the medial septum and dorsal hippocampus on memory acquisition. Pharmacol. Biochem. Behav.

Khanegheini, A., Nasehi, M., Zarrindast, M.R., 2015. The modulatory effect of CA1 GABAb receptors on ketamine-induced spatial and non-spatial novelty detection deficits with respect to $\mathrm{Ca}(2+)$. Neuroscience 305, 157-168.

Lamarre, Y., Mercier, L.A., 1971. Neurophysiological studies of harmaline-induced tremor in the cat. Can. J. Physiol. Pharmacol. 49, 1049-1058.

Li, T., Qadri, F., Moser, A., 2004. Neuronal electrical high frequency stimulation modulates presynaptic GABAergic physiology. Neurosci. Lett. 371, 117-121.

Ling, D.S., Benardo, L.S., 1994. Properties of isolated GABAB-mediated inhibitory postsynaptic currents in hippocampal pyramidal cells. Neuroscience 63 , 937-944.

Malatynska, E., Serra, M., Ikeda, M., Biggio, G., Yamamura, H.I., 1988. Modulation of GABA-stimulated chloride influx by beta-carbolines in rat brain membrane vesicles. Brain Res. 443, 395-397.

Malatynska, E., Giroux, M.L., Dilsaver, S.C., Schwarzkopf, S.B., 1992. Bidirectional effect of beta-carboline agonists at the benzodiazepine-GABAA receptor 
chloride ionophore complex on GABA-stimulated 36Cl- uptake. Brain Res. Bull. 28, 605-611

McNamara, R.K., Skelton, R.W., 1996. Baclofen, a selective GABAB receptor agonist, dose-dependently impairs spatial learning in rats. Pharmacol. Biochem. Behav. 53, 303-308

Mondadori, C., Jaekel, J., Preiswerk, G., 1993. CGP 36742: the first orally active GABAB blocker improves the cognitive performance of mice, rats, and rhesus monkeys. Behav. Neural Biol. 60, 62-68.

Moura, D.J., Rorig, C., Vieira, D.L., Henriques, J.A., Roesler, R., Saffi, J., Boeira, J.M., 2006. Effects of beta-carboline alkaloids on the object recognition task in mice. Life Sci. 79, 2099-2104.

Myhrer, T., 2003. Neurotransmitter systems involved in learning and memory in the rat: a meta-analysis based on studies of four behavioral tasks. Brain Res. Brain Res. Rev. 41, 268-287.

Nakagawa, Y., Takashima, T., 1997. The GABA(B) receptor antagonist CGP36742 attenuates the baclofen- and scopolamine-induced deficit in Morris water maze task in rats. Brain Res. 766, 101-106.

Nakagawa, Y., Ishibashi, Y., Yoshii, T., Tagashira, E., 1995. Involvement of cholinergic systems in the deficit of place learning in morris water maze task induced by baclofen in rats. Brain Res. 683, 209-214.

Nasehi, M., Jamshidi-Mehr, M., Khakpai, F., Zarrindast, M.R., 2014. Possible involvement of CA1 5-HT1B/1D and 5-HT2A/2B/2C receptors in harmaline-induced amnesia. Pharmacol. Biochem. Behav. 125, 70-77.

Nasehi, M., Ketabchi, M., Khakpai, F., Zarrindast, M.R., 2015. The effect of CA1 dopaminergic system in harmaline-induced amnesia. Neuroscience 285, 47-59

Nasehi, M., Meskarian, M., Khakpai, F., Zarrindast, M.R., 2016. Harmaline-induced amnesia: possible role of the amygdala dopaminergic system. Neuroscience 312, 1-9.

Nazari-Serenjeh, F., Rezayof, A., Zarrindast, M.R., 2011. Functional correlation between GABAergic and dopaminergic systems of dorsal hippocampus and ventral tegmental area in passive avoidance learning in rats. Neuroscience 196, $104-114$.

Paulsen, O., Moser, E.I., 1998. A model of hippocampal memory encoding and retrieval: gABAergic control of synaptic plasticity. Trends Neurosci. 21, 273-278.

Paxinos, G., Franklin, K.B.J., 2001. The Mouse Brain in Stereotaxic Coordinates, 2nd ed. Academic Press.

Pitsikas, N., Rigamonti, A.E., Cella, S.G., Muller, E.E., 2003. The GABAB receptor and recognition memory: possible modulation of its behavioral effects by the nitrergic system. Neuroscience 118, 1121-1127.

Quevedo, J., Vianna, M.R., Martins, M.R., Barichello, T., Medina, J.H., Roesler, R. Izquierdo, I., 2004. Protein synthesis, PKA, and MAP kinase are differentially involved in short- and long-term memory in rats. Behav. Brain Res. 154, 339-343.

Rommelspacher, H., Strauss, S., Lindemann, J., 1980. Excretion of tetrahydroharmane and harmane into the urine of man and rat after a load with ethanol. FEBS Lett. 109, 209-212.
Rook, Y., Schmidtke, K.U., Gaube, F., Schepmann, D., Wunsch, B., Heilmann, J., Lehmann, J., Winckler, T., 2010. Bivalent beta-carbolines as potential multitarget anti-Alzheimer agents. J. Med. Chem. 53, 3611-3617.

Saha, N., Chugh, Y., Sankaranaryanan, A., Sharma, P.L., 1993. Effects of post-training administration of (-)-baclofen and chlordiazepoxide on memory retention in ICRC Swiss mice: interactions with GABAA and GABAB receptor antagonists. Pharmacol. Toxicol. 72, 159-162.

Shahidi, S., Komaki, A., Mahmoodi, M., Lashgari, R., 2008. The role of GABAergic transmission in the dentate gyrus on acquisition, consolidation and retrieval of an inhibitory avoidance learning and memory task in the rat. Brain Res. 1204, 87-93.

Skerritt, J.H., Macdonald, R.L., 1984. Benzodiazepine receptor ligand actions on GABA responses. Beta-carbolines, purines. Eur. J. Pharmacol. 101, 135-141.

Splettstoesser, F., Bonnet, U., Wiemann, M., Bingmann, D., Busselberg, D., 2005 Modulation of voltage-gated channel currents by harmaline and harmane. Br. J. Pharmacol. 144, 52-58.

Stackman, R.W., Walsh, T.J., 1994. Baclofen produces dose-related working memory impairments after intraseptal injection. Behav. Neural Biol. 61, $181-185$.

Stuchlik, A., Vales, K., 2009. Baclofen dose-dependently disrupts learning in a place avoidance task requiring cognitive coordination. Physiol. Behav. 97, 507-511.

Weiss, M., Buldakova, S., Dutova, E., 1995. Interaction of the beta-carboline harmaline with a GABA-benzodiazepine mechanism: an electrophysiological investigation on rat hippocampal slices. Brain Res. 695, 105-109.

Welsh, J.P., 1998. Systemic harmaline blocks associative and motor learning by the actions of the inferior olive. Eur. J. Neurosci. 10, 3307-3320.

Yamauchi, T., 2005. Neuronal Ca2+/calmodulin-dependent protein kinase II-discovery, progress in a quarter of a century, and perspective: implication for learning and memory. Biol. Pharm. Bull. 28, 1342-1354.

Yousefi, B., Nasehi, M., Khakpai, F., Zarrindast, M.R., 2012. Possible interaction of cholinergic and GABAergic systems between MS and CA1 upon memory acquisition in rats. Behav. Brain Res. 235, 231-243.

Zarrindast, M.R., Lahiji, P., Shafaghi, B., Sadegh, M., 1998. Effects of GABAergic drugs on physostigmine-induced improvement in memory acquisition of passive avoidance learning in mice. Gen. Pharmacol. 31, 81-86.

Zarrindast, M.R., Khodjastehfar, E., Oryan, S., Torkaman-Boutorabi, A., 2001. Baclofen-impairment of memory retention in rats: possible interaction with adrenoceptor mechanism(s). Eur. J. Pharmacol. 411, 283-288.

Zarrindast, M.R., Shamsi, T., Azarmina, P., Rostami, P., Shafaghi, B., 2004. GABAergic system and imipramine-induced impairment of memory retention in rats. Eur. Neuropsychopharmacol. 14, 59-64.

Zarrindast, M.R., Massoudi, R., Sepehri, H., Rezayof, A., 2006. Involvement of $\mathrm{GABA}(\mathrm{B})$ receptors of the dorsal hippocampus on the acquisition and expression of morphine-induced place preference in rats. Physiol. Behav. 87, 31-38. 